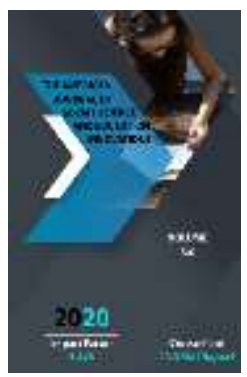

\title{
Use Of Appellatives In Mother-Child Interaction
}

Nodira Ikromovna Umarova

EFL Teacher, National University Of Uzbekistan, Tashkent, Uzbekistan

\footnotetext{
Journal Website:

http://usajournalshub.c

om/index,php/tajssei

Copyright: Original content from this work may be used under the terms of the creative commons attributes 4.0 licence.
}

\section{ABSTRACT}

This article is devoted to discussing the mother-child interaction in modern Uzbek society and lexical peculiarities of Uzbek mothers' speech by using appellatives. Communicative competences were classified in terms of social status of mothers. The article presents the structure and content of the linguistic concept of motherhood, the theoretical analysis of motherhood as a social institution, the concept of the social role and the role of women in society, as well as the sociolinguistic analysis of the speech portraits of the mother.

\section{KEYWORDS}

Motherhood, mother-child interaction, communication, appellatives, Uzbek mothers, child, communicative competence, family, society, upbringing.

\section{INTRODUCTION}

It is very important for parents to be able to communicate openly and effectively with their children. Open, effective communication benefits not only the children, but every member of the family. Relationships between parents and their children are greatly improved 
when there is effective communication taking place. In general, if communication between parents and their children is good, then their relationships are good as well. Good communication skills will benefit children for their entire lives. Children begin to form ideas and beliefs about themselves based on how their parents communicate with them. When parents communicate effectively with their children, they are showing them respect. Children then begin to feel that they are heard and understood by their parents, which is a boost to self-esteem $[5,9]$.

Motherhood is a manifestation of great love for a little child, which begins to be laid in the first hours of conception of the fetus, and not at all when the baby is born. Mother is the most important person in the child's life. Therefore motherhood is given such an important role.

The pedagogical concept of motherhood by N.E.Rudova also reflects the idea of motherhood guarantees human reproduction both physically and socioculturally. Motherhood is life-forming natural genetic principle of personality, integrated value of individual consciousness realized by the mother the power of sacrificial love in activities to ensure harmonious development a child in upbringing and educational service to the human race $[6,8]$.

Appellatives are the most widespread tools in a communication of a mother with a child. Uzbek mothers as well as other nationalities address variously to their children. Age, marital status, profession, religion and other social factors of Uzbek mothers indicate the differentiation of communicative behavior and style towards their children. Moreover, through their communicative skills mothers become an example for their children and impact either positively or negatively to the upbringing of a child.

\section{Main Part}

Traditionally, the increased attention of psychoanalysts to the topic of interaction in the mother-child dyad is associated with the name of $Z$. Freud. The psychoanalyst considered the roles of the mother and father differently, defining the mother as a key figure in the formation of basic personality traits at the oral stage of development (the stage of infancy), and the father during the phallic stage $[1,3]$.

To describe the lexical component in the communication of a mother with a child, we turn primarily to the appellatives. Under appellatives we understand we understand an appeal - a proper name or a common noun in the function of addressing the interlocutor [11, 32]. The available material makes it possible to classify appellatives used by a mother into proper names and common nouns. So, proper names serve as the leading way of addressing a mother to a child. Some of Uzbek mothers in this case actively use word formation, mainly the suffixation. For example: Fayyoza, Fayyozakhon, Fayyozochka, Fayyozik, Fayyozchik, Fazya.... There are mothers who prefer to use common nominal derivatives. For example: Dilechka, Dilya, Dilbar or Gulechka, Gulya, Guzal.

Common nouns used in communication with a child are more diverse. There are more derived words observing here. We have divided common nouns into the following groups:

a) By family affiliation, by kinship: my daughter (my daughter, my daughter, my daughter), my son (my son, my son, my son), my child / father (means the mother of the father of a parent, mostly by using their names);

b) Zoomorphism: my teddy bear, my hare, my chicken, my little fox 
c) By external real or attributed qualities: my beauty (my beauty), my little one, my sweetie, my affectionate, my brave;

d) By gender: my son (lion son, father son, wedding boy), my daughter (mother daughter, mother daughter, pop daughter).

e) By using cartoon or fairy tales heroes names: Cinderella (Zollushkam meni, Oy qizim meni), my snow-white .

It should be noted that Uzbek mothers in modern society very often use foreign words when communicating with a child. Russian words are used especially often. For example, zemlyanichka moya (my strawberry), docha (my daughter), krasotulka (my beauty), kudryashulka (my curly hair)...

Studies have shown that modern Uzbek mothers sometimes use English words when communicating with their child. For example, one of the mothers to the question "What words do you scold a child when he makes you angry with?" the participant answered the "stupid". Or to the question "what is your favorite word for pampering your child?" we had the answer in English "Honey". As a result, we can say that no matter what language mothers speak their children feel and understand them well.

In terms of religion the Uzbek mothers are considered to be very polite in interaction with a child. Because as the other religions Islam call on people to be kind and cultivated in communication with everyone. Many researches were done on this topic by Uzbek scientists. They say that the pictures and shapes of the people are beautifully created. This wisdom requires that their behavior be beautiful as well. The more a person beautifies his picture and biography, his inner world, the closer he reaches the level of perfection. Therefore, children should adopt gentleness and forgiveness as their motto. The stronger the attention, the more opportunities they have in the presence of their parents. Parents who want their children to have a good culture of behavior should set an example for their children in this regard.

We can say that treatment is like a blessing of life in the family, it's a flashlight for homeowners. At the same time, when parents see each other's shortcomings or misbehavior, it is commendable to criticize in front of children, to find out the cause of the incident in a calm manner, to solve the problem with sincere words, without embarrassment [3,3].

Our research shows that representatives of variety professions amongst mothers in Uzbek society use different and significant speaking style with a child. According to the data collected after holding a questionnaire with Uzbek mothers, women who have an administrative position often use more careful words, while a group of mothers who do business or workers contact with their child ordinarily. Some psychologists explain that by the fact that mother-bosses are not able to spend enough time with children, thus they try to compensate such an omission with kindness and politeness. Furthermore, these types of mothers get used to have commanding tone and they fell guilty before their family. On the other hand, mothers who are also very busy, but do not have to be a leader interact with their children somewhat differently. They are free in communication with a child, in various life situations they may appeal to a child differently.

Mothers who are busy with the household chores are not particularly differing in their interaction ways with a child from the mothers who work. They just do it more often rather than others. 


\section{RESULTS AND DISCUSSIONS}

Over the centuries, from the works of ancient thinkers to modern times, the social role of women has been interpreted in different ways. Currently, one of the important spheres of a woman's self-realization is motherhood, and in psychology there is a unity of views on the paramount importance of the role of the mother at certain stages of growing up. In addition, psychologists and psychiatrists are almost unanimous that the social role of a mother is a special state of a woman's personality, which determines the specific forms of her behavior (including speech) in communicating with her child.

Communication is the basis of family relationships. In no social environment does the value of communication fully manifest itself as in family life. Communication is a spiritual and cultural wealth. But it varies depending on the environment, circumstances, the other person's mood, mood, and needs. There is no one who communicates with everyone in the same order, in the same way $[4,31]$. It cannot be denied that the mother has a special place in the upbringing of the child. Researchers have found that children who are raised by their mother, who always feel her care and affection, grow up to be healthier, smarter, more educated, and more cheerful than children of mothers who are completely separated from their children. A U.S. study found that more than half of those incarcerated were malnourished. It is also clear from this example that no one but the mother can give a great feeling of love to the child [10, 4]. Hence, the way of communication of mother with a child can be determined as one of the main factors in child's upbringing.

The analysis show that a mother-child interaction in modern Uzbek society is peculiar in terms of its' politeness and abundance of different words and phrases. With the use of appellatives mothers are able to express their love and feelings, which are felt by children and directly affects their mood. Especially children at the age under three tend to imitate every gesture and speech spoken by the mother.

Thus, they develop linguistic abilities and fill a vocabulary base, on the basis of which children will build their social circles.

\section{CONCLUSION}

It is very important for children to have stable and loving relationships with their caregivers usually their mothers. Because of the love and affection they receive, they learn to rely on the caregiver and to trust her. As they grow they learn by watching and imitating her, as well as by getting instructions and guidance from her. When they manage to do something, their learning is reinforced by her praise and approval. This is a normal scenario. For this the mother does not need any special training, this kind of caregiving comes naturally and instinctively to her. This is the ideal environment for a child to develop his potential to the maximum $[2,5]$.

In life very often there are cases when adults are called not by their given names or by abbreviated names. They are addressed by common nouns that were used by their mothers in childhood. Thus, this trend is turning into a tradition and sometimes children change their names to nicknames. So, after the analyzing a mother-child interaction with using of appellatives we came to conclusion that mothers referring to children use completely different words and phrases. These phrases remain in the lives of children forever influencing their character, preferences, behavior and even the future. 
The purpose of the study was to analyze and compare mother-child interaction ways in the examples of appellatives. The analysis show that mothers at various religion, profession, age and status use different words of address towards a child. Moreover, the study explores the concept of motherhood and communicative features of mother's speech in the social role of motherhood.

\section{REFERENCES}

1. Freyd Z., Vvedeniye v psikhoanaliz. Leksii/ 3. M.: 2008. - p. 334-348.

2. Improving Mother/child Interaction To Promote Better Psychosocial Development in Children. Programme on mental health. Geneva. 1997.p.36

3. Kattaboyem M., Muloqot va muomila madaniyati. "Khidoyat" orta maxsus islom bilim yurti, muslim.uz -April 09, 2018

4. Khuseynova A., Farzand tarbiyasidagi avlodlar ortasidagi oilaviy qadriyatlarning akhamiyati. Farzand tarbiyasida otaning ma'suliyati, vazifasi va majburiyati. Muammo va yechim.Tashkent - 3 avgust 2018 y. b.186

5. Kristin Zolten, M.A. \& Nicholas Long, Parent/Child Communication, Ph.D., Department of Pediatrics, University of Arkansas for Medical Sciences Artwork by Scott Snider. 1997, 2006 - p. 9

6. Rudova N.Y., Sistema vospitaniya tsennostnogo otnosheniya k materinstvu:SPb., 2009. - p.22

7. Sachs, J. The Adaptive Significance of Linguistic of Prelinguistic Infants. Talking to Children: Language input and acquisition / ed. by C.E. Snow, C. A. Ferguson. -1977. - P. 51-61.

8. Skinner, B.F. Contingencies of reinforcement a theoretical analysis / B.F.
Skinner. - N.Y.: Appleton Century Crofts, 1969. - $319 \mathrm{p}$.

9. Skinner, B.F. Verbal behavior / B.F. Skinner. - Englewood Cliffs; N.J.: Prentice Hall, 1957. $-478 \mathrm{p}$.

10. Tashmukhamedova D.G., Farzand tarbiyasidagi avlodlar ortasidagi oilaviy qadriyatlarning akhamiyati. Farzand tarbiyasida otaning ma'suliyati, vazifasi va majburiyati. Muammo va yechim.Tashkent 3 avgust 2018 y. b.186

11. Varlamova O.N. Rechevouy portret jenshini $v$ sotsialno-rolevoy roli materi. Krasnoyarsk - 2017. s.180.

\section{DICTIONARIES}

1. The American Heritage Dictionary of the English Language [Electronic resource].http://www.ahdictionary.com

2. Akhmanova O.S. linguistic terms reference . -2nd edition, stereotype / Moscow: Editorial, URSS, 2004. $-576 \mathrm{~s}$. 